\title{
Building QSAR for HTS in vitro assays - a study for the prediction of Aryl hydrocarbon receptor activators
}

\author{
Ahmed M Abdelaziz ${ }^{1,2^{*}}$, Alexander Safanyaev ${ }^{3}$, Vladimir Palyulin $^{3}$, Igor V Tetko ${ }^{1,2}$ \\ From 8th German Conference on Chemoinformatics: 26 CIC-Workshop \\ Goslar, Germany. 11-13 November 2012
}

The Aryl hydrocarbon receptor (AHR) is a ligand-dependent transcription factor that, normally inactive, upon activation responds to exogenous and endogenous chemicals with the induction/repression of expression of large battery of genes. This induces diverse biological and toxic effects in a wide range of tissue. To evaluate the structural characteristics of small molecules responsible for AHR binding and toxicity, cross-validated qualitative QSAR models were developed using the free tool OCHEM (http://ochem.eu) by ASNN, random forests, J48 and MLR analyses and applicability domain was estimated. For the subset of most confident predictions the achieved accuracy can reach as high as $95 \%$. Fragmental analysis of the chemical structures was applied to better understand the origin of AHR binding affinity. Analysis confirms several chemical scaffolds of halogenated aromatic hydrocarbons (HAHs) and polycyclic aromatic hydrocarbons (PAHs) as activators of the AHR. The high accuracy of in silico techniques in modeling the in vitro assay results endorses QSAR as a promising technique in predictive toxicology.

\section{Author details}

'Institute of Structural Biology, Helmholtz Zentrum Muenchen, Neuherberg, Germany. ${ }^{2}$ ADMET GmbH, Neuherberg, Germany. ${ }^{3}$ Department of Chemistry, Moscow State University, Moscow, Russian Federation.

Published: 22 March 2013

\footnotetext{
* Correspondence: contact@amaziz.com

'Institute of Structural Biology, Helmholtz Zentrum Muenchen, Neuherberg, Germany
}

Full list of author information is available at the end of the article
doi:10.1186/1758-2946-5-S1-P51

Cite this article as: Abdelaziz et al:: Building QSAR for HTS in vitro assays - a study for the prediction of Aryl hydrocarbon receptor activators. Journal of Cheminformatics 2013 5(Suppl 1):P51.

\section{Publish with ChemistryCentral and every scientist can read your work free of charge \\ "Open access provides opportunities to our colleagues in other parts of the globe, by allowing anyone to view the content free of charge." \\ W. Jeffery Hurst, The Hershey Company. \\ - available free of charge to the entire scientific community \\ - peer reviewed and published immediately upon acceptance \\ - cited in PubMed and archived on PubMed Central \\ - yours - you keep the copyright \\ Submit your manuscript here: \\ http://www.chemistrycentral.com/manuscript/

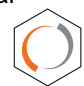 \\ Chemistry Central}

